



\section{FINANCING FOR SUSTAINABLE URBANIZATION IN ASIA AND THE PACIFIC}

Proceedings of the ADB-Asian Think Tank Development Forum 2017

SEPTEMBER 2017 
(c) 2018 Asian Development Bank

6 ADB Avenue, Mandaluyong City, 1550 Metro Manila, Philippines

Tel +632632 4444; Fax +6326362444

www.adb.org

Some rights reserved. Published in 2018.

ISBN 978-92-9261-098-2 (print), 978-92-9261-099-9 (electronic)

Publication Stock No. TCS189206-2

http://dx.doi.org/10.22617/TCS189206-2

The views expressed in this publication are those of the authors and do not necessarily reflect the views and policies of the Asian Development Bank (ADB) or its Board of Governors or the governments they represent.

ADB does not guarantee the accuracy of the data included in this publication and accepts no responsibility for any consequence of their use. The mention of specific companies or products of manufacturers does not imply that they are endorsed or recommended by ADB in preference to others of a similar nature that are not mentioned.

By making any designation of or reference to a particular territory or geographic area, or by using the term "country" in this document, ADB does not intend to make any judgments as to the legal or other status of any territory or area.

This work is available under the Creative Commons Attribution 3.0 IGO license (CC BY 3.0 IGO)

https://creativecommons.org/licenses/by/3.0/igo/. By using the content of this publication, you agree to be bound by the terms of this license. For attribution, translations, adaptations, and permissions, please read the provisions and terms of use at https://www.adb.org/terms-use\#openaccess

This CC license does not apply to non-ADB copyright materials in this publication. If the material is attributed to another source, please contact the copyright owner or publisher of that source for permission to reproduce it. $A D B$ cannot be held liable for any claims that arise as a result of your use of the material.

Please contact pubsmarketing@adb.org if you have questions or comments with respect to content, or if you wish to obtain copyright permission for your intended use that does not fall within these terms, or for permission to use the ADB logo.

Notes:

In this publication, “\$” refers to United States dollars.

Corrigenda to ADB publications may be found at http://www.adb.org/publications/corrigenda

All photos in this publication are from ADB. 


\section{ACKNOWLEDGMENTS}

The organizers gratefully acknowledge the following for their support and hard work in coordinating the event.

\section{Partners}

Asian Development Bank

Institute of Policy Studies of Sri Lanka

\section{Keynote Speaker}

Patali Champika Ranawaka

Welcome Remarks

Dushni Weerakoon

Sri Widowati

\section{Moderators}

Shiro Patrick Armstrong

Nonarit Bisonyabut

Derek Brien

Presenters

Marife Ballesteros

Anbumozhi Venkatachalam

Enkhbaigali Byambasuren

Tran Kim Chung

Shujaat Farooq

Carunia Mulya Hamid Firdausy

Sanjeev Gupta

Kithmina Hewage

Xiaoming Huang

Radhicka Kapoor

Dongxiang Li

Keiichiro Oda

Cyn-Young Park

Ram Kumar Phuyal

Bilesha Weeraratne

Li Xu

Naoyuki Yoshino

Qiangwu Zhou

Juzhong Zhuang

Organizing Team

Dongxiang Li

Dushni Weerakoon

Aiko Kikkawa Takenaka

Juzhong Zhuang

\section{Support Team}

Sharon Lynn Dela Torre

Nayomi Jayakody

Erickson Mercado

Shihara Maduwage

Aleli Rosario

Charmaine Wijesinghe 


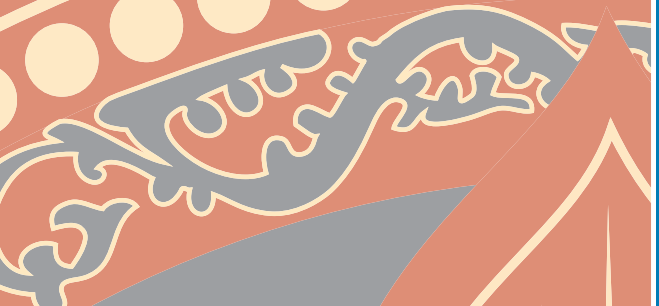
s.

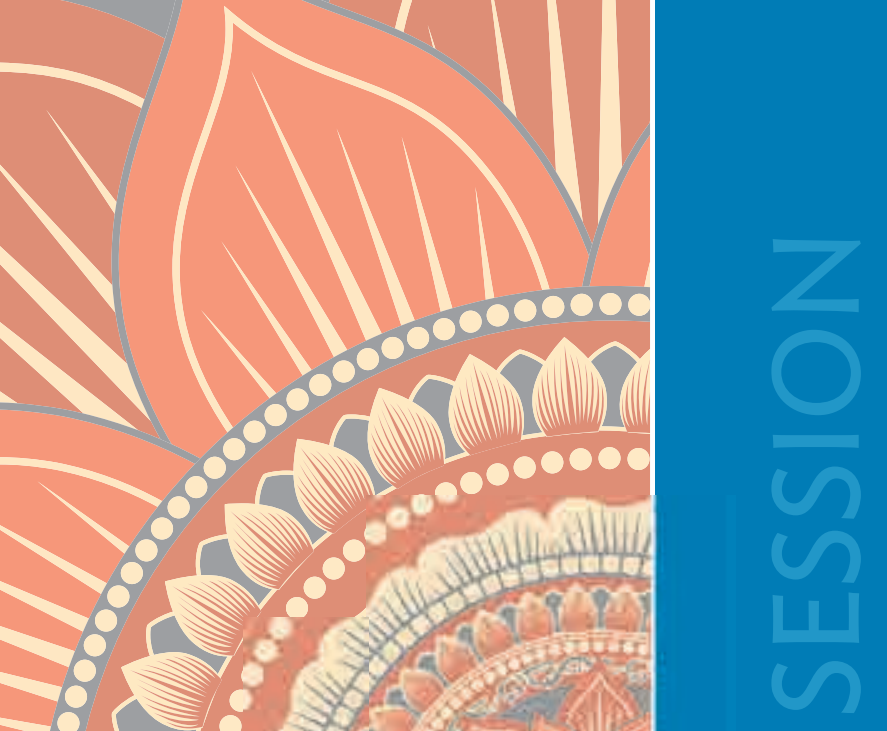

OPENING CEREMONY

के

1
0
0

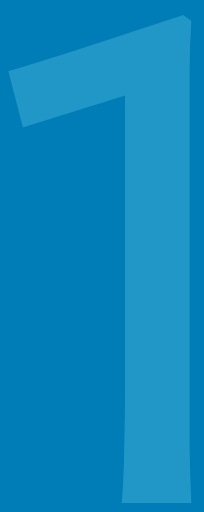

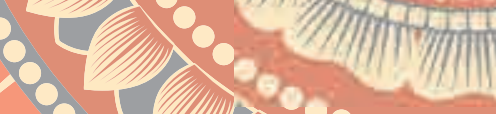

1002000000

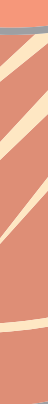

190
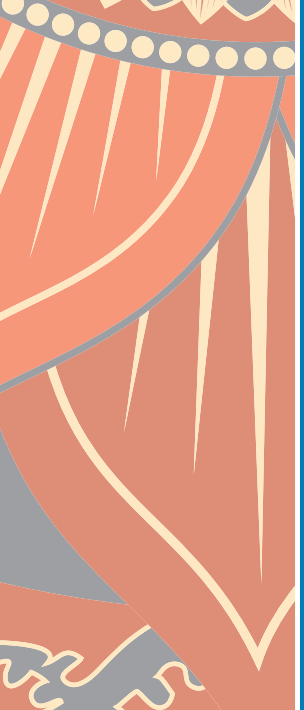

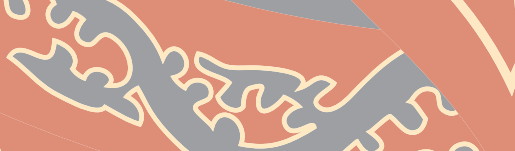

$\sim \Omega($

$\rightarrow>$ 


\section{SESSION 1: Opening Ceremony}

The Asian Development Bank (ADB) in partnership with the Institute of Policy Studies of Sri Lanka (IPS) organized the ADB-Asian Think Tank Development Forum 2017 in Colombo, Sri Lanka on 20-21 September 2017. It was attended by over 70 representatives from 25 countries in Asia and the Pacific and seven international organizations. With the theme of Financing for Sustainable Urbanization in Asia and the Pacific, the forum served as a platform for sharing knowledge and building the capacity of prominent think tanks in the region.

Megapolis and Western Development Minister Patali Champika Ranawaka delivered the keynote address, highlighting the timeliness and appropriateness of the theme in addressing the urbanization challenges facing developing economies in the region. Following the presentations on economic outlooks by representatives of ADB, the People's Republic of China (PRC), India, and Sri Lanka, research papers of think tank members were presented on the themes of public-private partnership (PPP) and other innovative and emerging infrastructure financing schemes, and urban infrastructure and service delivery. Participants shared country experiences, challenges, and opportunities for urban infrastructure projects, and their financing options. Discussions followed, complemented by lectures and presentations highlighting the fiscal implications of urbanization and the region's growing infrastructure needs. 


\section{WELCOME REMARKS}

\section{Good urban planning is crucial for creating sustainable cities that are environment-friendly and less resource-intensive.}

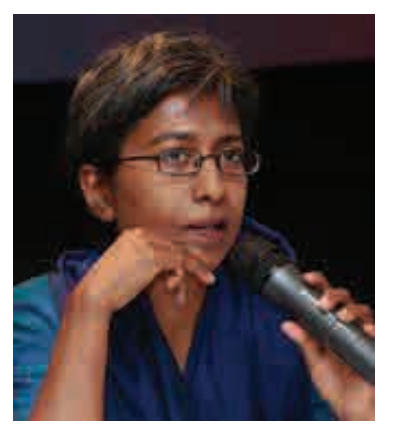

Dushni Weerakoon of IPS welcomed the participants to the 2017 development forum. She underscored the relevance of the theme to the region's development agenda, and noted that Asia is undergoing a rapid process of economic transformation and urbanization with increased demand for affordable housing, more efficient transport systems, and better urban social services. The region is positioned to benefit from good urban planning to address issues of congestion, pollution, and income disparities within and across cities, Weerakoon said. She highlighted that good planning for urban development is crucial for creating sustainable cities that are environment-friendly and less resource-intensive. Similar to many Asian nations, Sri Lanka is undergoing rapid economic transformation that involves infrastructure developments. The Western Region Megapolis Planning Project is the government's flagship construction project with an estimated cost of $\$ 40$ billion over the next 15 years. Weerakoon noted that financing is the most common development challenge faced by developing countries, and she emphasized the importance of exploring efficient financing mechanisms to fund urbanization projects in Asia and the Pacific. Paper presentations and country case studies presented at the forum would discuss these schemes and help identify solutions that could be replicated in other countries. She encouraged everyone to participate in discussions and thanked ADB for being a key driver for this knowledge-sharing event.

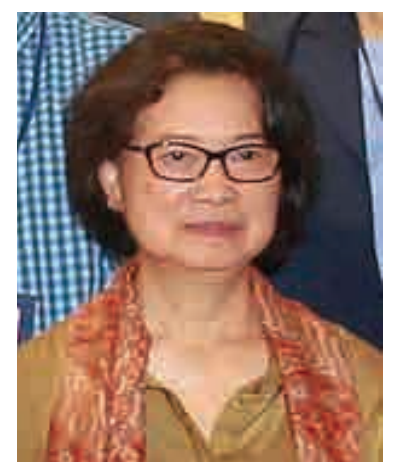

Sri Widowati of the ADB resident mission in Sri Lanka expressed appreciation to IPS and the Government of Sri Lanka for cohosting the forum. Widowati stressed the value of the ADB-Asian Think Tank Development Forum in enhancing think tanks' policy advisory capacities, given the significance of think tanks in shaping public policy of ADB's developing member countries, and that the network also provides $A D B$ with firsthand knowledge and experiences to share with client countries. She also conveyed ADB's continued support to Sri Lanka's urban development programs, including a strategy to support growth by boosting urban agglomerations to attract high-quality investments and improve governance. She encouraged participants to contribute to peer learning and discuss options applicable to their countries. 


\section{KEYNOTE ADDRESS}

\section{"Sustainability in all spheres of activity will greatly shape the future of our world."}

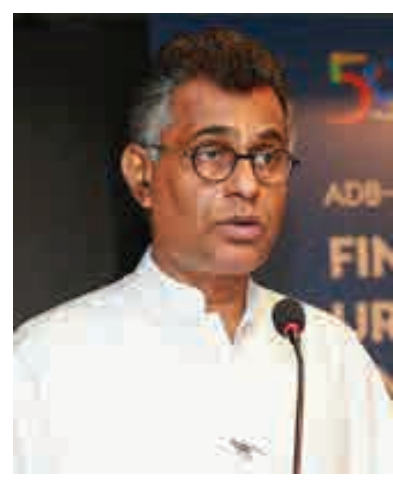

Sri Lanka's Minister of Megapolis and Western Development, Patali Champika Ranawaka, highlighted the timeliness and appropriateness of the conference theme and commented that "sustainability in all spheres of activity will greatly shape the future of our world." He noted that the main urbanization challenges in South Asian countries are from unplanned, unsustainable, unhygienic, uncontrolled, unsafe, and ad hoc urbanization. Official data estimate that $53 \%$ of the population in Asia will be urbanized by 2025, and added that countries like Sri Lanka will face many issues associated with massive urbanization.

Minister Ranawaka cited the benefits of urbanization, such as the increase in productivity of the economies through agglomeration and efficient resource mobilization, supported by expanding consumer markets for goods and services. He also pointed out that negative consequences include the migration of low-skilled workers without adequate employment opportunities, and environmental problems triggered by higher population density, such as pollution, floods, and water scarcity. As an island, Sri Lanka's urbanization experience is unique in that urban settlements are found along its coastal belt he said. The ongoing Western Region Megapolis Planning Project is expected to drive economic growth in the western region. Since the project is capital-intensive and costs about $\$ 40$ billion, the government has engaged in PPPs to ensure sustainable project financing. Minister Ranawaka said the PPP model will harness private-sector resources to achieve national goals. In closing, he urged the participants to deliberate and study best options and practical approaches to solve common challenges in the region.

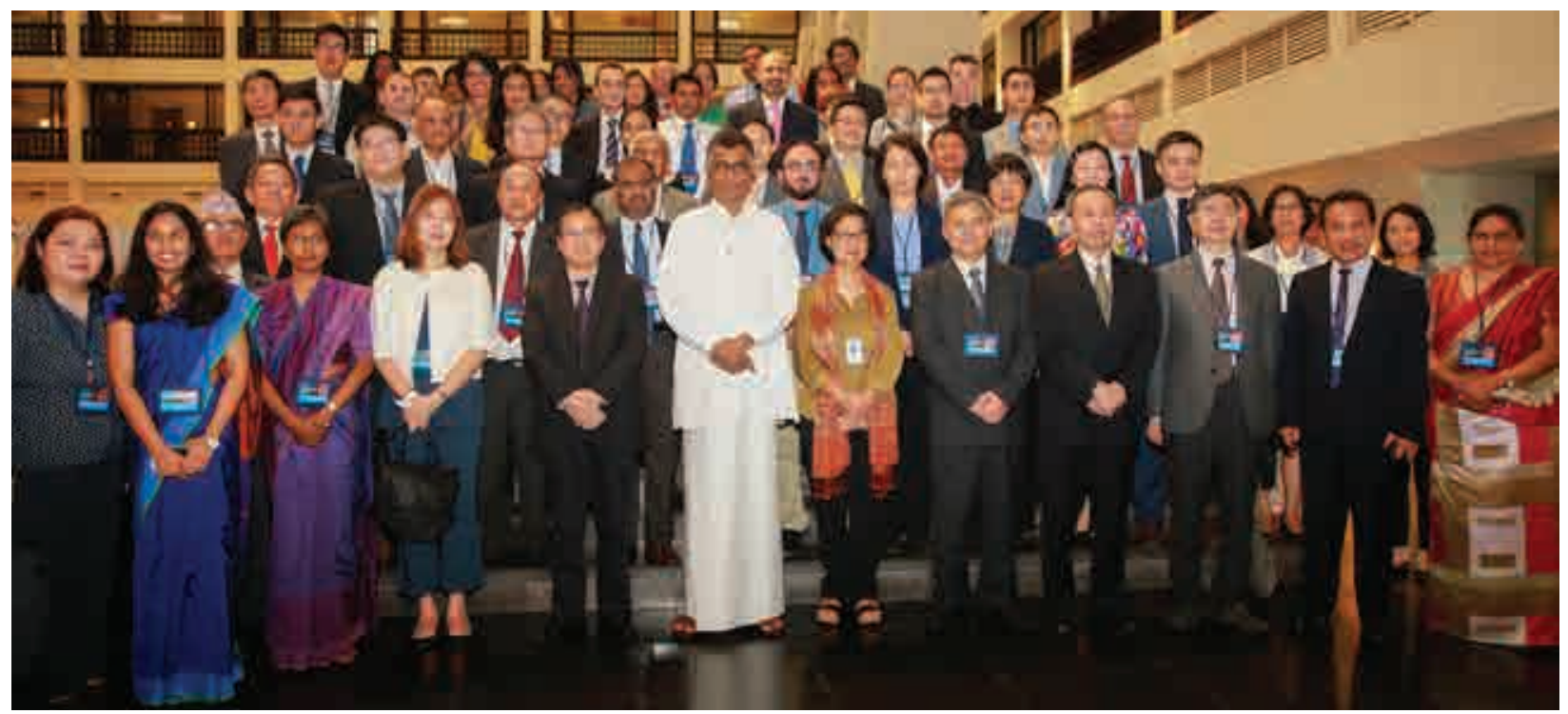




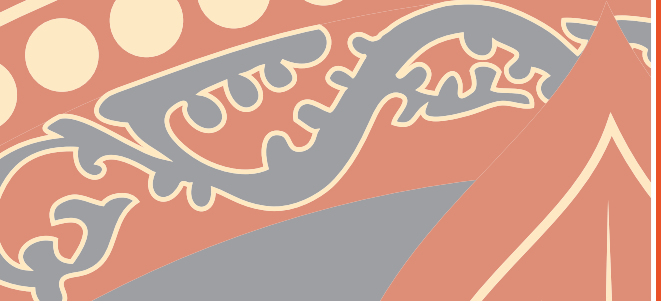

$\sqrt{5}$
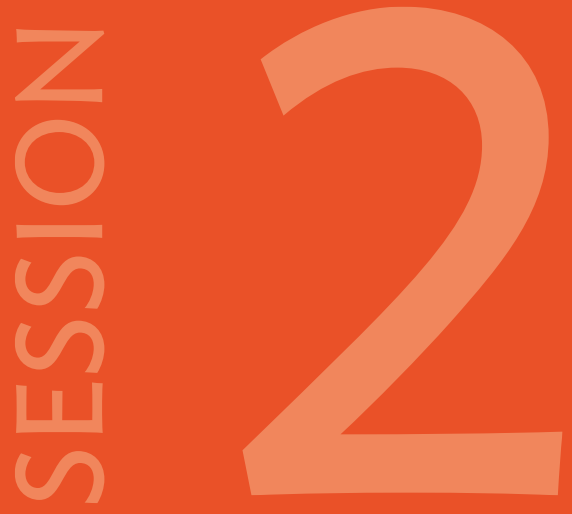

\section{REGIONAL AND COUNTRY ECONOMIC OUTLOOKS}

y
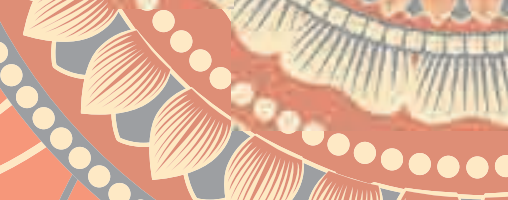

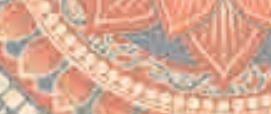



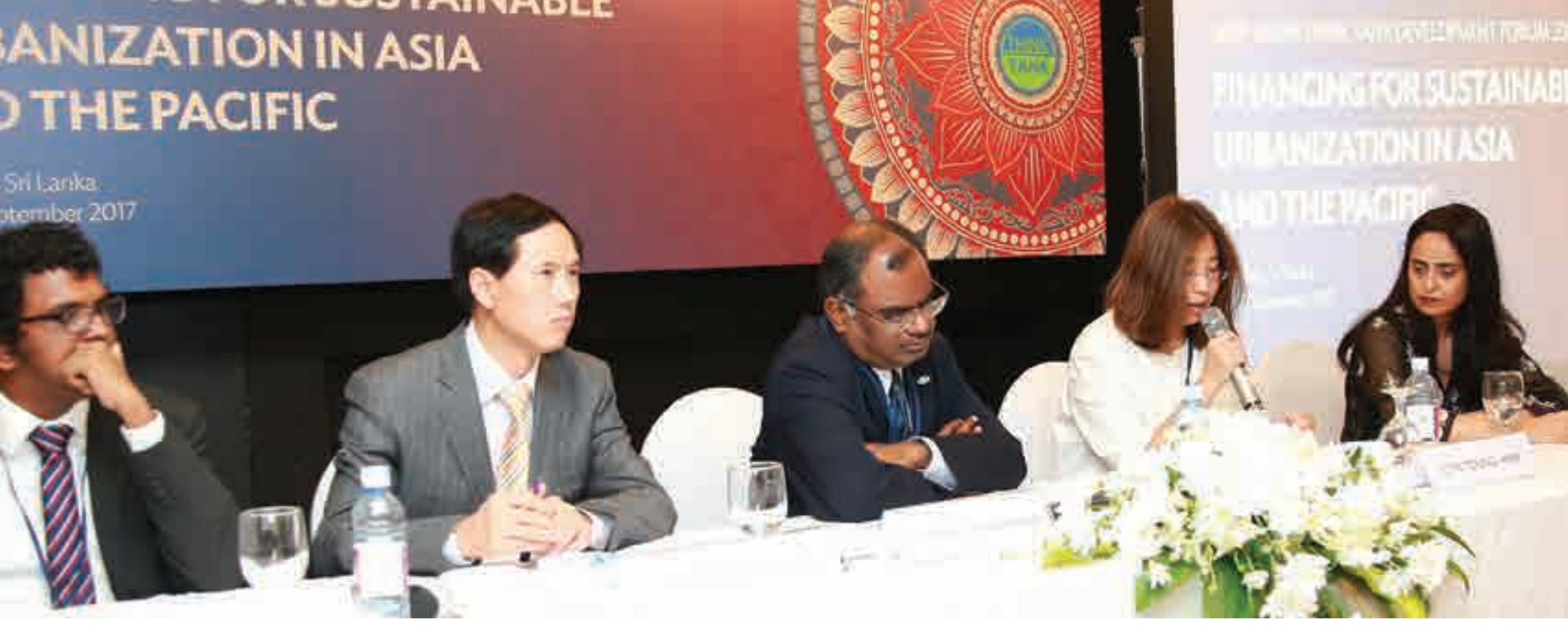

\section{SESSION 2: Regional and Country Economic Outlooks}

\section{Robust economic growth in Asia is expected.}

Anbumozhi Venkatachalam of the Economic Research Institute for ASEAN and East Asia moderated the session.

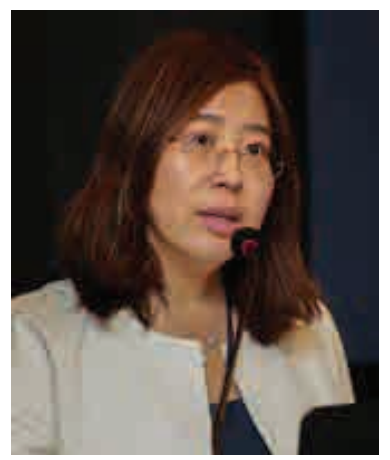

\section{Regional Integration in Asia: Trends and Issues}

Cyn-Young Park of ADB presented trends and issues on regional integration and the development outlook in Asia. She reported that developing Asia has seen robust economic growth, with the rate forecast at 5.9\% in 2017 and 5.8\% in 2018. The outlook is supported by improvements in advanced economies and growing resilience in regional and domestic demand in Asia and the Pacific, Park said. Modest increases in commodity prices and economic recovery in the Russian Federation provide a partial boost in Central and West Asia. Asia leads the global trade recovery, but world trade growth remains weak, mostly due to uncertainties and changes in politics and policies related to mega trade deals, Park noted.

Regional integration in Asia and the Pacific is maturing but the degree of integration varies across subregions. Park noted that ADB introduced the Asia-Pacific Regional Integration Index (APRII) to measure the degree of integration across six dimensions, (i) trade and investment, (ii) money and finance, (iii) the regional value chain, (iv) infrastructure and connectivity, (v) movement of people, and (vi) institutional and social integration. APRII indicates that Southeast Asia appears to be the most advanced in regional integration, largely driven by trade, investment, and regional value chains. Compared to regions such as Europe, Asia scores low in institutional and social integration. However, trends show that intraregional trade linkages continue to strengthen even as Asia's global value chain participation stagnates due to its maturity. Global foreign direct investment (FDI) inflows to Asia dipped in 2016, but intraregional FDI flows continued to rise, Park said. She noted that 
Asian financial markets and systems are still more integrated globally than regionally, and that equity market returns are more vulnerable than local currency bond markets to global external shocks.

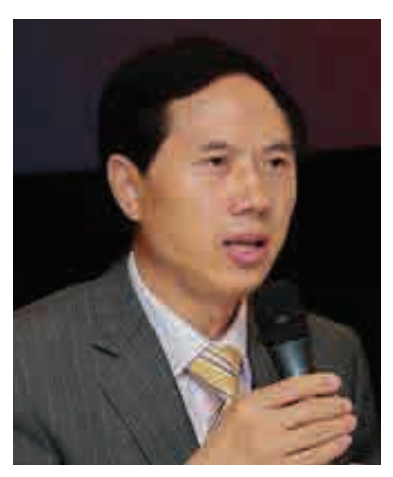

\section{People's Republic of China's Economic Outlook}

Qiangwu Zhou of the International Economics and Finance Institute presented the economic outlook of the PRC. The economy has been showing steady growth with employment and other growth drivers gaining momentum above projections. Structural adjustments are being advanced and major improvements in infrastructure were achieved as over 22,000 kilometers of high-speed rail lines came into service. Major fiscal and monetary policy initiatives, including structural reforms, were undertaken in recent years, Zhou said. Fiscal policy remains proactive and expansionary in 2017, incurring about $\$ 360$ billion deficits to be used mainly to compensate for tax cuts and to cover social security and the costs of other livelihood programs. Monetary policy continues to be prudent and neutral. Money supply and aggregate financing are forecasted to grow around $12 \%$ in 2017. The government will continue to fine-tune policies according to the economic situation to maintain a stable financial system and prevent systematic risks, Zhou noted. To enable the market to take a decisive role in resource allocation, the PRC will continue to deepen reforms that streamline government administration, delegate more powers, and improve regulation and service. The government will likewise continue to support world economic globalization by strengthening international cooperation and fight against protectionism, Zhou added.

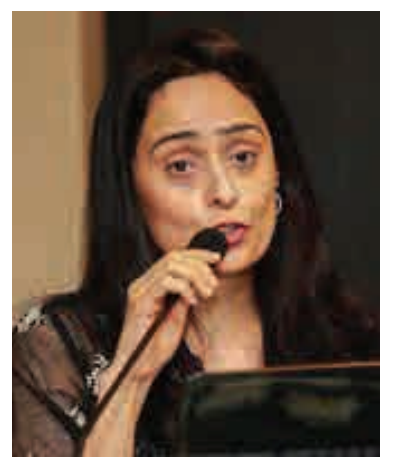

\section{India's Economic Outlook}

Radhicka Kapoor of the Indian Council for Research on International Economic Relations discussed India's economic outlook. India has been touted as a "bright spot" in the global economy, but is now showing signs of a growth slowdown, Kapoor said. In the first quarter of 2017, the growth rate plunged to a 3 year low of $5.7 \%$, resulting from declines in consumption, private investments, and the gross fixed capital formation as a percentage of gross domestic product (GDP). The fall in private sector investment is partly a consequence of balance sheet problems that plague the banking and corporate sectors. Nonperforming assets as a percentage of gross loans stand at 9.1\%, one of the highest in the world, Kapoor also noted. She added that there is also an urgent need to strengthen the finance sector by cleaning up bank balance sheets because India's growth rate rests on a revival of investment, which in turn is contingent on solving the twin balance sheet problem.

A significant challenge for India is the creation of productive jobs for its rapidly rising young population. Based on Labour Bureau data, total employment fell from 481.3 million in 20132014 to 468.6 million in 2015-2016. Further, the National Sample Survey Office estimated that $92.8 \%$ of workers were in the informal sector in 2011-2012. It is essential that reforms be initiated to promote inclusive economic growth and job creation, Kapoor added. 


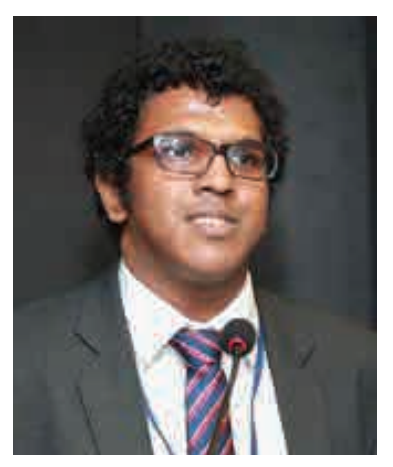

\section{Sri Lanka's Economic Outlook}

Kithmina Hewage of IPS presented Sri Lanka's economic outlook. He said that an unsustainable fiscal deficit has been accumulating in recent years. Despite improvements, deficits average $7 \%$ to $8 \%$ of GDP, fueling high and volatile inflation. Debt accumulation also increased the country's exposure to internal and external shocks. Government revenue mobilization also failed to adequately cover public recurrent expenditures and Sri Lanka's current macroeconomic position is much weaker than other countries of similar economic standing, he said. Since its graduation to low-middle income status, Sri Lanka is no longer qualified to access concessionary loans, and borrowing from international capital markets increased the debt burden in recent years.

Hewage said Sri Lanka faces a twin challenge of stabilizing its macroeconomic fundamentals while catalyzing economic growth by attracting FDI and increasing export revenues. Given that a debt-led development strategy is no longer feasible, Sri Lanka is in urgent need to reorient its economy toward a more sustainable means of finance, driven by private sector participation. 

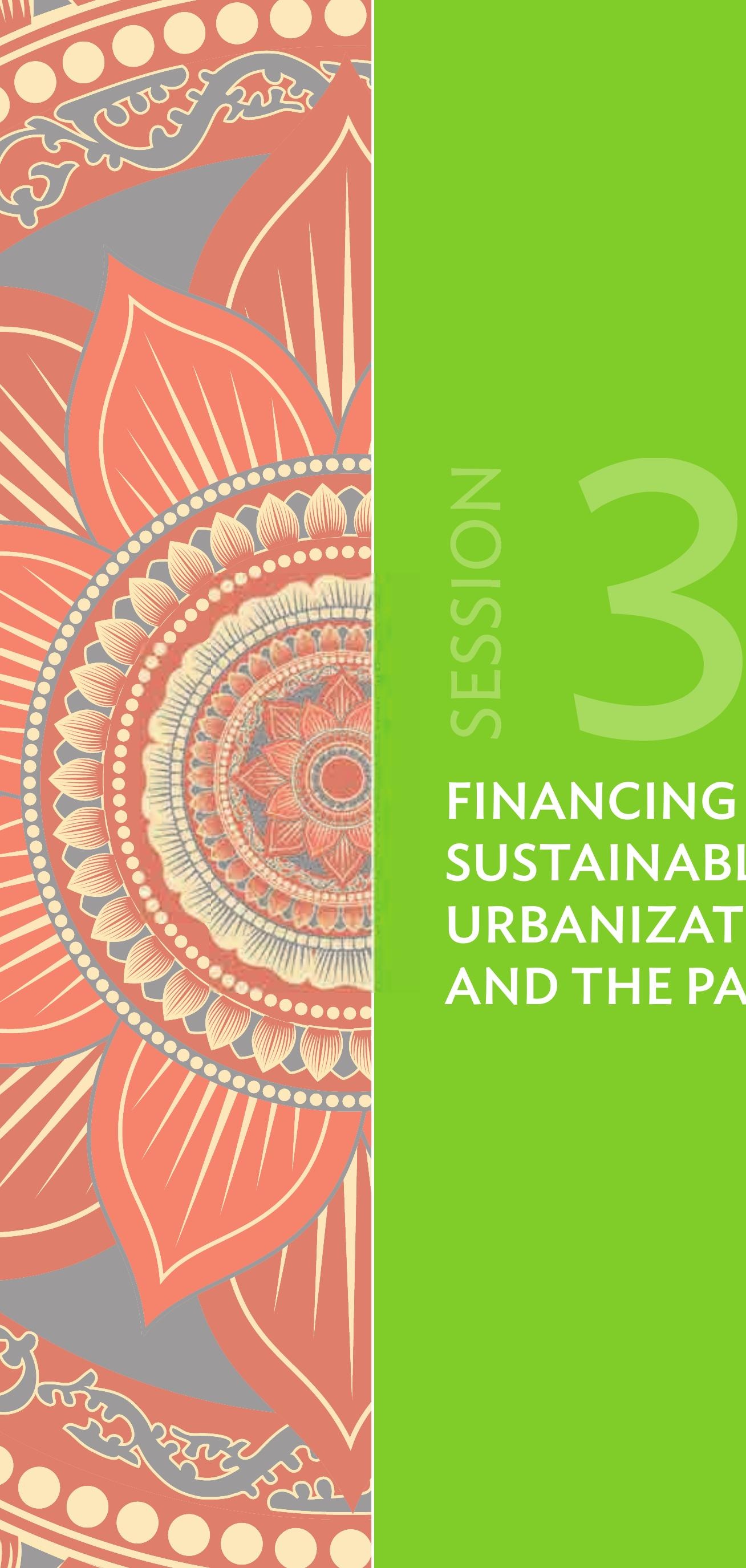

FINANCING FOR SUSTAINABLE URBANIZATION IN ASIA AND THE PACIFIC 


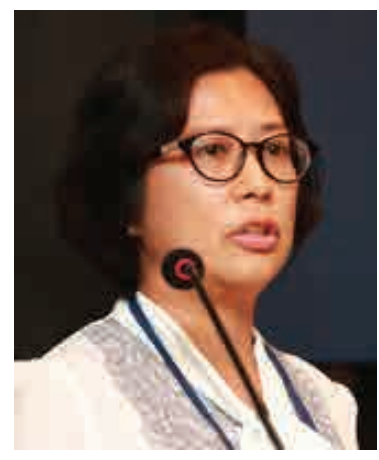

\section{Financing for Urban Infrastructure in the Era of Climate Change and Disaster Risks: Philippines}

Marife Ballesteros of the Philippine Institute for Development Studies presented a paper she coauthored with Gilberto Llanto. For the past 16 years, urban infrastructure financing in the Philippines has come to reflect the need to build infrastructure resilient to the adverse impacts of environmental and climate change. Two issues clearly stand, Ballesteros said. The first issue is finding cost-effective infrastructure design by improving information and assessment capacities of government agencies. It raises issues on the acceptable standards of infrastructure resilience and the role of insurance in balancing risks. The second issue is finding the balance between public and private financing. Ballesteros said the government must bring in the private sector more by offering incentives to finance the development of climate-resilient urban infrastructure. The government relies mainly on the national budget and external funds to finance such projects. Private sector financing is limited, partly because the investment climate is poor and the capacity to engage in climate finance is lacking, she said, and amid growing fiscal pressures, it would be prudent for the government to increase private sector participation and its contribution to green infrastructure investments. The government must also adopt new and innovative sources of financing such as betterment levies or taxes on polluters, Ballesteros added.

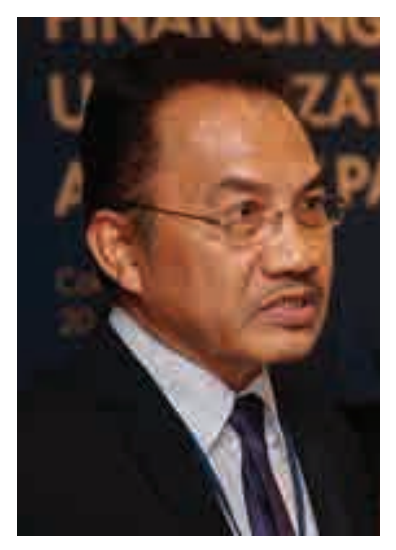

\section{Potential Financial Instruments toward Sustainable Urban Infrastructural Development in Indonesia}

\section{Carunia Mulya Firdausy of the Economic Research}

Centre-Indonesian Institute of Sciences presented his paper, Potential Financial Instruments toward Sustainable Urban Infrastructural Development in Indonesia, and highlighted concerns about the development of the urban infrastructure needed for Indonesia to sustain its development. While rapid urbanization puts huge pressure on basic services, including education, public health, water supply, housing, energy, and transportation, government funds to support urban infrastructure are inadequate, Firdausy said. For 2015-2019, of the total budget needed to finance infrastructure, only about $41.3 \%$ was provided by the central and regional governments. The paper confirms results from existing studies that private business has a crucial role in sustaining urban infrastructural development. Besides the financial instruments already implemented to develop urban infrastructure, instruments such as corporate bonds, project bonds, and Sharia bonds (Sukuk) can be considered. The paper proposes to maximize use of such private debt instruments and challenges the government to provide regulations, incentives, and guarantees to help attract investment from the business community. 


\section{Innovative financing schemes that encourage the participation of the private sector will help raise funds for infrastructure projects.}

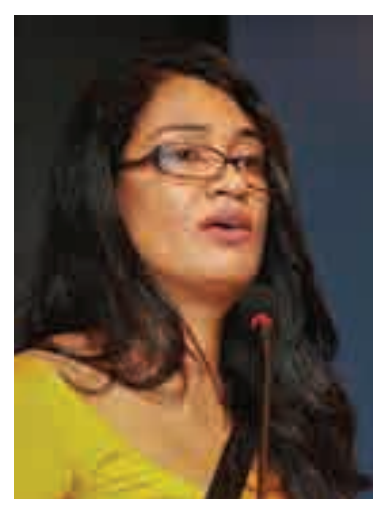

\section{Sustainable Financing for Urban Solid Waste Disposal Services in Sri Lanka}

Bilesha Weeraratne of IPS presented her paper, Sustainable Financing for Urban Solid Waste Disposal Services in Sri Lanka, and noted that Sri Lanka is rapidly urbanizing but with limited preparedness and finances to address the challenges. In particular, urban solid waste disposal needs urgent attention. Although municipal councils and other local institutions manage the disposal of solid waste, funding for their services comes from the central government and revenue collected by Municipal Solid Waste Management Services (MSWMS). Insufficient central government funding and negligible collections by the MSWMS hamper the ability of local authorities to provide solid waste management services, Weeraratne said. To enhance sustainability, other financing options including property tax, user fees, extended producer responsibility, private sector participation, and results-based financing can be considered. Sri Lanka would benefit from a combination of financing strategies that share the responsibility between consumers, producers, and the state. Schemes such as the Pay As You Throw scheme, Extended Producer Responsibility systems, and private sector participation could be tapped to mobilize resources, Weeraratne said.

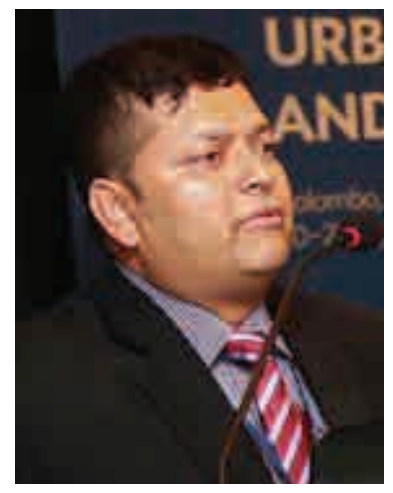

Dynamics of Financing and Governances of Melamchi Water Supply Project in Kathmandu, Nepal: Lessons Learned

Ram Kumar Phuyal of Tribhuvan University's Center for Economic Development and Administration discussed his paper Dynamics of Financing and Governances of Melamchi Water Supply Project in Kathmandu, Nepal: Lessons Learned. Rapid urbanization and unplanned housing growth, lack of sustainable water sources, inadequate investment, and weak management resulted in water supply shortages and poor service delivery in Kathmandu, Phuyal said. With the help of development partners including ADB, the Government of Nepal implemented the Melamchi Water Supply Project to meet growing demand for drinking water and sanitary services from residents of Kathmandu Valley. The project started in 2001 and was due to be completed in 7 years. However, political unrest, frequent changes in management, weak governance, and increased uncertainty in the political and development sectors have hampered completion of the project to date. At the project start, regional banks and external funding agencies committed full support, but with changes in the governance in Nepal, the project funding norms and regulations also changed several times and led to increased uncertainty in the project's funding and operation, Phuyal noted. The project was restructured in 2008 
and 2014, reducing its costs and activities substantially. Assessment of financing issues indicated that the delay in completion cost more than $\$ 186$ million a year in lost revenue for Kathmandu's water distribution system. The full economic cost is nearly 10 times greater if charges for providing existing bulk water supply services are considered, Phuyal said. The analysis provides important and useful insights for planning and project implementation. The government and key water sector institutions are also pursuing reforms that cover institutional, governance, operational, and financial actions.

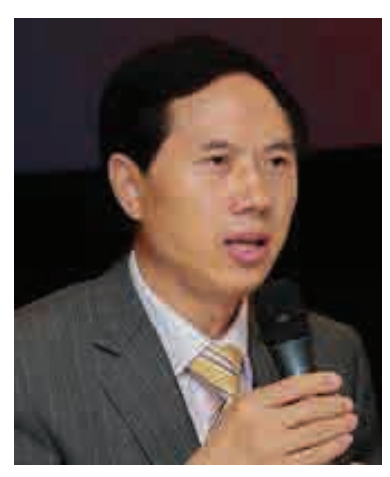

\section{Financing the Belt and Road Initiative of the People's Republic of China}

Qiangwu Zhou of the International Economics and Finance Institute shared the PRC's experience on financing the Belt and Road Initiative (BRI). The BRI was launched in 2013 to promote infrastructure development and interconnectedness among countries, coordinate national economic and development strategies, and achieve common prosperity. Sustainable financing is a key requirement, said Zhou. He noted that funding mainly comes from (i) the central government's official development assistance, development financing, policy or commercial banks, and state-owned enterprises; and (ii) multilateral development banks that provide expertise for building large-scale, cross-border projects. Among other financing sources being considered are: national funds from countries along the "Belt and Road," sovereign wealth funds, institutional investors, and private investors. Considering that diverse financing mechanisms are needed, 27 participating countries endorsed the Financing Guidelines for the Belt and Road during the "Belt and Road" Summit Forum in May 2017. The guidelines call for tapping a multi-financing system through types of cooperation that include joint financing, parallel financing, tripartite cooperation, and multiparty cooperation, among others.

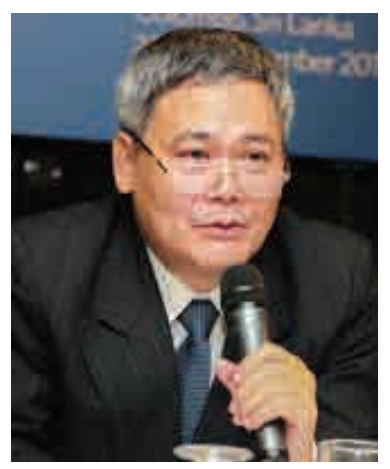

\section{Land Conversion during the Urbanization Process in Viet Nam: Current Status, Problems, and Solutions}

Tran Kim Chung of Viet Nam's Central Institute for Economic Management shared the highlights of his paper, Land Conversion during the Urbanization Process in Viet Nam: Current Status, Problems and Solutions. Viet Nam experienced rapid urbanization as exemplified by an increase in urban population by 9.1 million people from 2005 to 2015, and a large portion of agricultural land converted to industrial use. The widespread urbanization is mostly the cause of urban sprawl, wasted natural and human resources, underused industrial zones, and land conversion conflicts, among other issues. The study indicated these problems result mainly for two reasons: (i) urbanization and land conversion reflects a political desire more than the real need of economic development; and (ii) government management of land is weak, given that land valuation appears to benefit the state and enterprises more than the land owners. The suggested solutions are: (i) better urban planning for cities; (ii) creation of a real land market after the 2013 Land Law; (iii) transparency in the land transition from agriculture to urban; and (iv) enforcement of existing laws. 


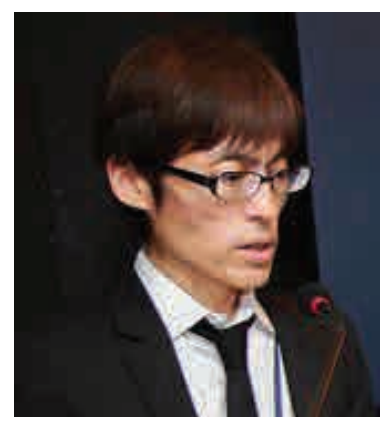

\section{Public-Private Partnerships with a Governmental Fund: An Optimal Incentive Device}

Keiichiro Oda of Japan's Research Institute of Economy, Trade and Industry presented his paper on public-private partnerships with governmental funds. The paper analyzes the incentive structure of PPP by setting up a model based on an incomplete contracting framework. The model shows that: (i) a bargaining game between the public sector and the private sector in PPP can function as a device to internalize the project's externalities; and that (ii) the involvement of a governmental fund interacting with the financial market can mitigate the moral hazard of related parties. The study considered a typical PPP project with two stages-building and operating - and where the government delegates all tasks to a consortium through a concession contract with private money used for the investment, which would create a moral hazard for the consortium. The first outcome of internalizing externalities can be achieved by incorporating mandatory renegotiation of the initial concession contract at the end of building phase.

A well-designed renegotiation can improve the investment by providing incentives to consortiums not to underinvest. The second outcome is achieved by effectively leveraging the governmental fund's governance role and its signaling effect to financial markets. Besides assuming expertise in policy evaluation, the fund can prompt the market to discipline the consortium's behavior, for example, through a decision to allow or not to allow the consortium to continue with the project contract. At the same time, the governmental fund can be given incentives to commit to monitoring the consortium as a way of sending positive signals to the financial market in which it raises money. 


\section{URBANIZATIONINASIA AND THE PACIFIC}

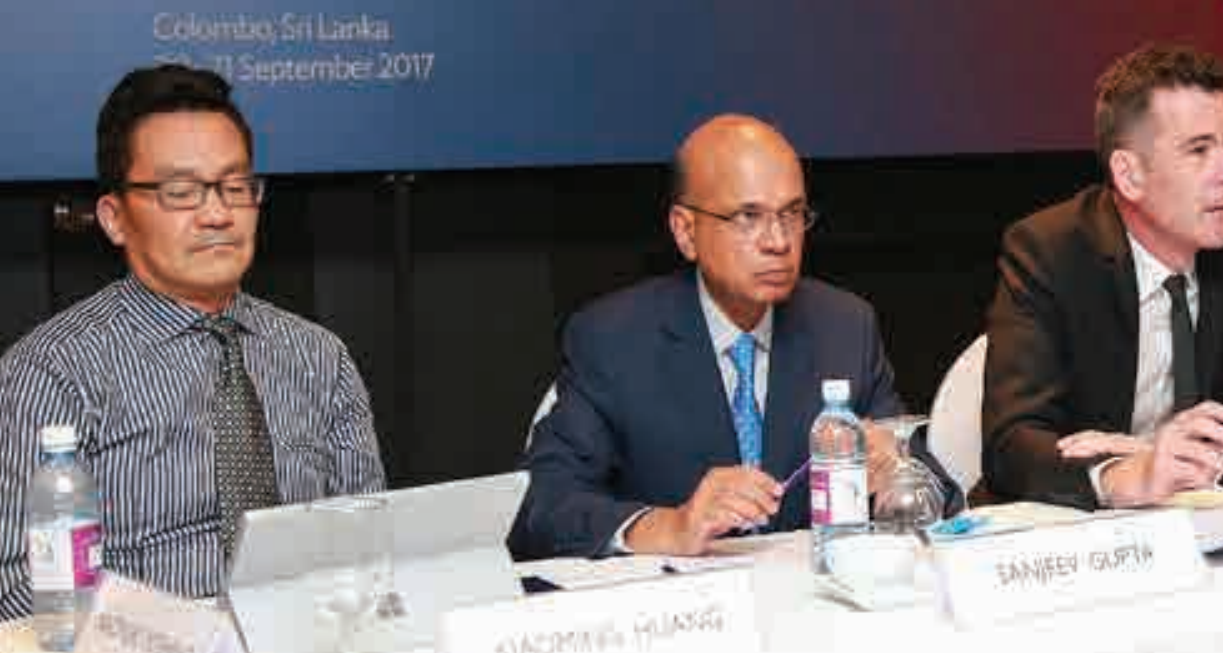

\section{Effective fiscal policy can help support sustainable infrastructure and ensure adequate provision of public services.}

Derek Brien of the Pacific Institute of Public Policy moderated this session.

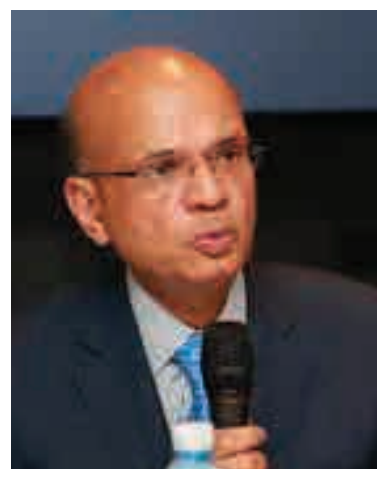

\section{Fiscal Implications of Urbanization}

Sanjeev Gupta of the International Monetary Fund-Fiscal Affairs Department discussed the fiscal implications of urbanization. Official statistics suggest the world's urban population quadrupled from 746 million in 1950 to 3.4 billion in 2014. Gupta said it is very likely that the actual number is much larger, and that governments are not keeping up with supplying services. Rapid urbanization presents a number of big challenges and it will bring about many positive and some potentially negative consequences. Urbanization spurs growth by increasing productivity, boosting innovation, inducing economies of scale, and offering better paying jobs. On the other hand, negative effects include air pollution, traffic congestion, expansion of slums, and increased income inequality.

Gupta pointed out that a key fiscal challenge is how to mobilize resources for cities to ensure sustainable provision of infrastructure and basic services. Rapid urbanization creates large infrastructure needs in developing countries and increases environmental damage. Urban areas generate $80 \%$ of the world's GDP and consume more than twothirds of its energy, generating $70 \%$ of global greenhouse gas emissions. Buildingsboth commercial and residential-account for a fifth of energy emissions while transportation accounts for a fifth of global carbon emissions. Gupta noted that the International Monetary Fund estimates the total cost of fossil fuel subsidies is $\$ 5.3$ trillion (or $6 \%$ of global GDP). If governments levy taxes on the externalities, this will: (i) reduce global carbon dioxide emissions by more than $20 \%$; (ii) cut primary deaths from air pollution by more than $50 \%$; and (iii) bring increased fiscal gains of $\$ 2.9$ trillion (3.6\% of world GDP) by lowering distortionary taxes and priority spending. 
Gupta discussed the options to mobilize resources for cities. Given budgetary constraints, governments need to reassess the design of intergovernmental fiscal frameworks. Local governments in developing countries collect on average less than $25 \%$ of their spending needs compared to $56 \%$ in more developed regions, which hampers their ability to finance urbanization. Improving fiscal arrangements (such as tax and expenditure assignments) between federal and local governments will be politically difficult to implement in the short term, he said. On average, developing countries lose about $40 \%$ of the value of their public investment because of inefficiencies in investment, while in emerging and low-income countries, investment losses are suggestive of weaknesses in the institutions that govern public investment. Gupta emphasized the need to look at federal and local public spending to generate savings that will make the fiscal space to create more infrastructure and basic social services.

It is also crucial to leverage innovative sources of finance, including user charges. Gupta noted that while assets under management controlled by the private finance are estimated to be worth $\$ 120$ trillion globally, infrastructure projects attract only $10 \%$ of this source of funding. The scope clearly exists for tapping these resources to finance infrastructure, he said. Another is maximizing the use of about $\$ 186.1$ billion a year available in official development assistance (ODA). Infrastructure projects account for only $23 \%$ of total ODA, showing there is much room for them to tap such funds.

Generating revenue from land assets through (i) land value capture (as successfully done by Brazil and Hong Kong, China); (ii) land leases and land sales (e.g., in the PRC); and (iii) land asset management (e.g., in Egypt and France) is also seen as a viable option to mobilize resources. Using PPPs to finance urban infrastructure requires a functioning framework to prevent contingent liabilities from overwhelming the budget, Gupta said. He concluded by saying that an effective fiscal policy can help support sustainable infrastructure and ensure an adequate provision of public services. Fiscal policy can also help mitigate the negative externalities generated by urban areas.

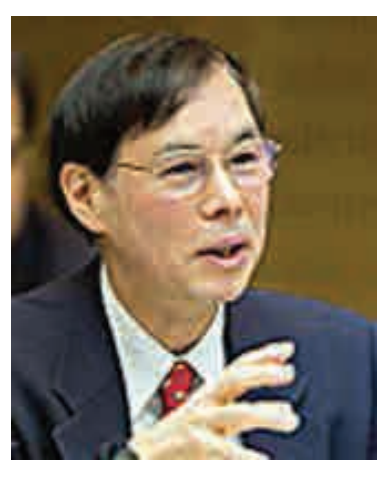

\section{Infrastructure Investment, Small and Medium-Sized Enterprises Promotion, and Education for Sustainable Growth}

Naoyuki Yoshino of the ADB Institute shared a video presentation in which he underscored the importance of spillover effects from infrastructure investment and how to use tax revenues created by the externality effects of infrastructure to attract private sector finance. He cited some case studies of infrastructure projects in Bangladesh, India, Japan, the Philippines, and Uzbekistan, which showed that infrastructure investment can create jobs, increase productivity, and enhance cross-border and regional connectivity. Yoshino pointed out that spillover tax revenues created by infrastructure investment should be returned to the investors to increase the rate of return and maximize profits thereby encouraging private companies to invest more. 
Yoshino explained that a combination of hard infrastructure, such as roads and railways; and soft infrastructure, such as education and other basic services, can contribute significantly to sustainable growth. Infrastructure investment coupled with investment in education has been proven to enhance economic impact. Secondary education and training can develop the skills and ability to go into business, and university education equips students with technological expertise that tends to benefit both government and industries. Yoshino also shared Japan's experience in implementing the hometown investment trust funds. The funds connect investors with personal knowledge and interest in their hometown to projects in the area. Individual investors can choose their preferred projects and make investments through the internet. One of the biggest applications of the funds in Japan is for wind power and solar power projects. They raise money from individuals interested in promoting green energy, with investments ranging from about $\$ 100$ to $\$ 5,000$ per investor.

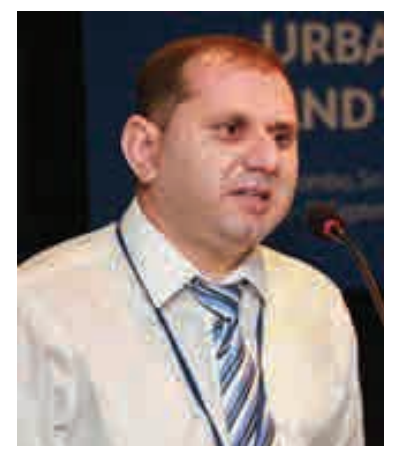

\section{The State of Urban Living: A Review of Housing Laws and Financing Instruments in Urban Pakistan}

Shujaat Farooq of the Pakistan Institute of Development Economics shared insights from his paper, The State of Urban Living: a Review of Housing Laws and Financing Instruments in Urban Pakistan. The country experienced one of the fastest urbanization rates in South Asia, he noted, with people living in cities increasing to half the country's population in 2017 from 17\% in 1951. By 2025, that is expected to increase to nearly $60 \%$, with about $15 \%$ of the total population living in 17 megacities. Although urbanization significantly contributed to GDP growth, poverty reduction, increased job opportunities, and the rise of a new middle-income class, infrastructure development has not kept pace to respond to the needs of the urban population, Farooq said. Pakistan faces a severe shortage of urban housing, with a backlog of about 9 million units. A huge percentage of urban people live in slum areas and in extremely crowded localities. Despite existing laws and ordinances, urban land management and housing development remain unregulated, especially for people on low and middle incomes. Housing financing options are mostly limited to high-income groups, Farooq noted. Overall, public policy toward a planned and stable urbanization is missing in Pakistan, and the role of local government in responding to urbanization must be clearly defined and their capacity upgraded to effectively manage urban development.

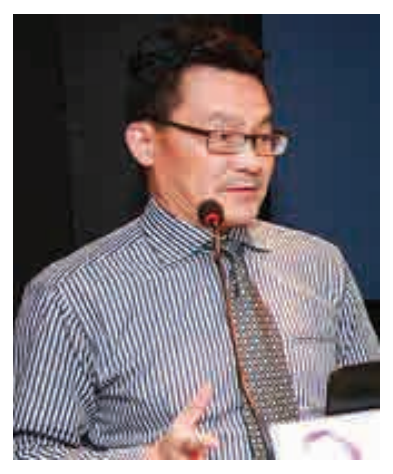

\section{Global Capital Supply and Sustainable Urbanization: Investment-Led Development Financing}

Xiaoming Huang of the Wellington Network of Asia-Pacific Research \& Policy, Victoria University of Wellington in New Zealand, highlighted the key results of his study in investmentled financing for sustainable urbanization. Urbanization involves infrastructure development projects-health service, housing, education, transportation, power supply, water supply, and even digital services, Huang said. Sustainable urbanization requires that investment in these areas be sustained. Such financing presents a challenge to both 
developing and developed economies. Huang cited the 2017 ADB report, Meeting Asia's Infrastructure Needs, which found that capital investment in infrastructure in the 45 developing economies in Asia will need $\$ 26$ trillion for 2015-2030, with \$1.7 trillion each year. He noted the chronic shortage of capital investment in the infrastructure sector versus the great need for it in coming decades, and argued that the missing link between investment and development is the inability of infrastructure development projects to attract sustainable investment.

Against this backdrop, Huang said a report from the United Nations Conference on Trade and Development for 2016 noted the PRC was for the second year running the world's second-largest provider of FDI; investing $\$ 188$ billion in 2016. Moreover, he noted a particular pattern in the structure of PRC capital in global investment. A Ministry of Commerce 2017 report showed that overseas assets held by PRC enterprises were worth $\$ 4.4$ trillion in 2016, and put their contracted infrastructure projects at \$1.1 trillion, Huang said. The engagement in PRC enterprises in infrastructure development projects around the world in the past 15 years marked a shift from intergovernmental development aid to PPP investment-led financing. This form of financing brings together the interests of PRC enterprises and other countries in international projects, and also brings public and private sector together as partners, Huang said. The investment-led development financing is able to channel effective, sustainable, state-insured capital investment directly to the infrastructure development project.

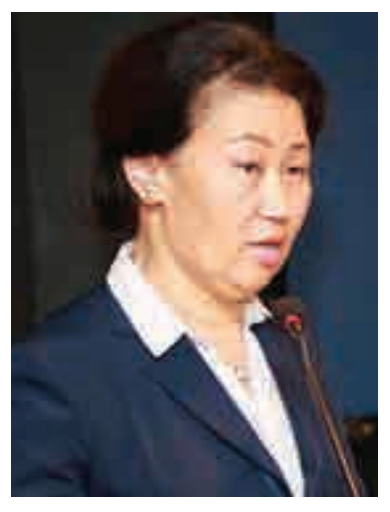

\section{Dynamic Relationship between Rural and Urban Areas}

Enkhbaigali Byambasuren of Mongolia's Analysis Group shared insights from her paper, Dynamic Relationship between Rural and Urban Areas, and discussed how migration patterns are linked to urban and rural development in Mongolia. The country's population is largely urban and increasingly concentrated in Ulaanbaatar, where $45 \%$ of Mongolia's total population lives. Between 2000 to 2014, the number of people in Ulaanbaatar doubled due to migration, Byambasuren said. Many of these migrants settled in informal communities of traditional ger dwellings around the city. As a result, about $60 \%$ of Ulaanbaatar's population was living in unplanned districts.

Better access to market, jobs, and basic social services, including education and health, are the primary attractions for people to migrate to urban settlements. Agriculture-dependent herders, for instance, leave their homes to find better opportunities if they lose most of their animals to drought or harsh winter conditions. Byambasuren argued that while it is common for governments to invest heavily on urban infrastructure, it would be prudent to accelerate development in rural areas. Investments could be made on enabling mechanisms such as farm-to-market roads, setting up rural amenities including schools and health centers, and on supporting small and medium-sized enterprises, which would inevitably create more jobs in rural areas. These investments are regarded as much less expensive than investing in infrastructure in the city, Byambasuren noted. Furthermore, she added that pursuing this nontraditional strategy will greatly help strengthen urban-rural linkages, solve city problems stemming from congestion, and achieve a balance in development. 


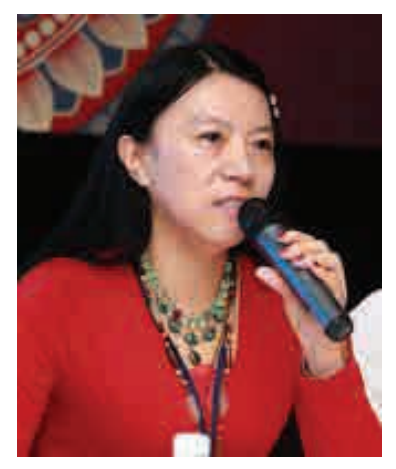

\section{Financing for Effective, Inclusive and Sustainable Urbanization-People's Republic of China Case}

Li Xu of the ADB Institute presented her paper, Financing for Effective, Inclusive and Sustainable Urbanization-People's Republic of China Case. The "people-oriented" new-type urbanization that started in 2014 covered three key questions: why finance, how to finance, and how to improve the efficiency of financing for sustainable urbanization. Why finance relates to what can be considered a reasonable scale for urbanization financing; how to finance relates to approaches for mobilizing urbanization funds; and how to improve efficiency relates to the financing mechanisms. Xu said new-type urbanization offers financing features: (i) from extensive and land-oriented to intensive, people-oriented high-quality; (ii) from "reinforced concrete" cities of the same image to characteristic cities and towns with "green hills, clear water and nostalgic elements"; and (iii) from local government financing vehicles and "land financing" to local financing with strict budget constraints on local government debt. Although implementing improvements and innovations in the local government debt system reduced nonstandard financing behaviors, some deep problems in systems and mechanisms persist. Financing bottlenecks continue and new problems emerged. Intensifying reforms, reducing institutional constraints, providing policy incentives, and diversifying to provide sustainable financing mechanisms are fundamental to realizing high-quality, efficient, inclusive, and sustainable urbanization, Xu added. 

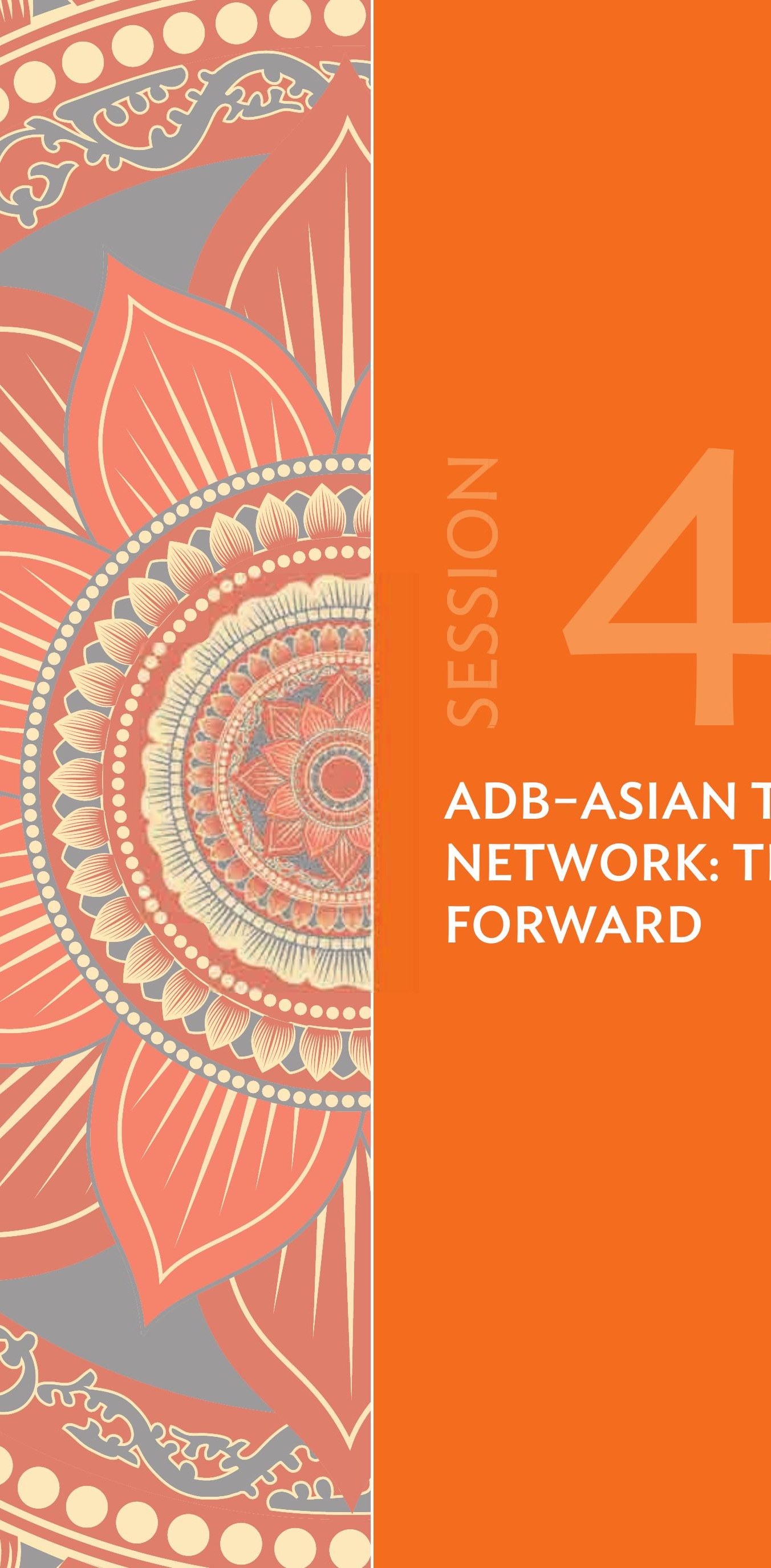

\section{ADB-ASIAN THINK TANKS NETWORK: THE WAY FORWARD}




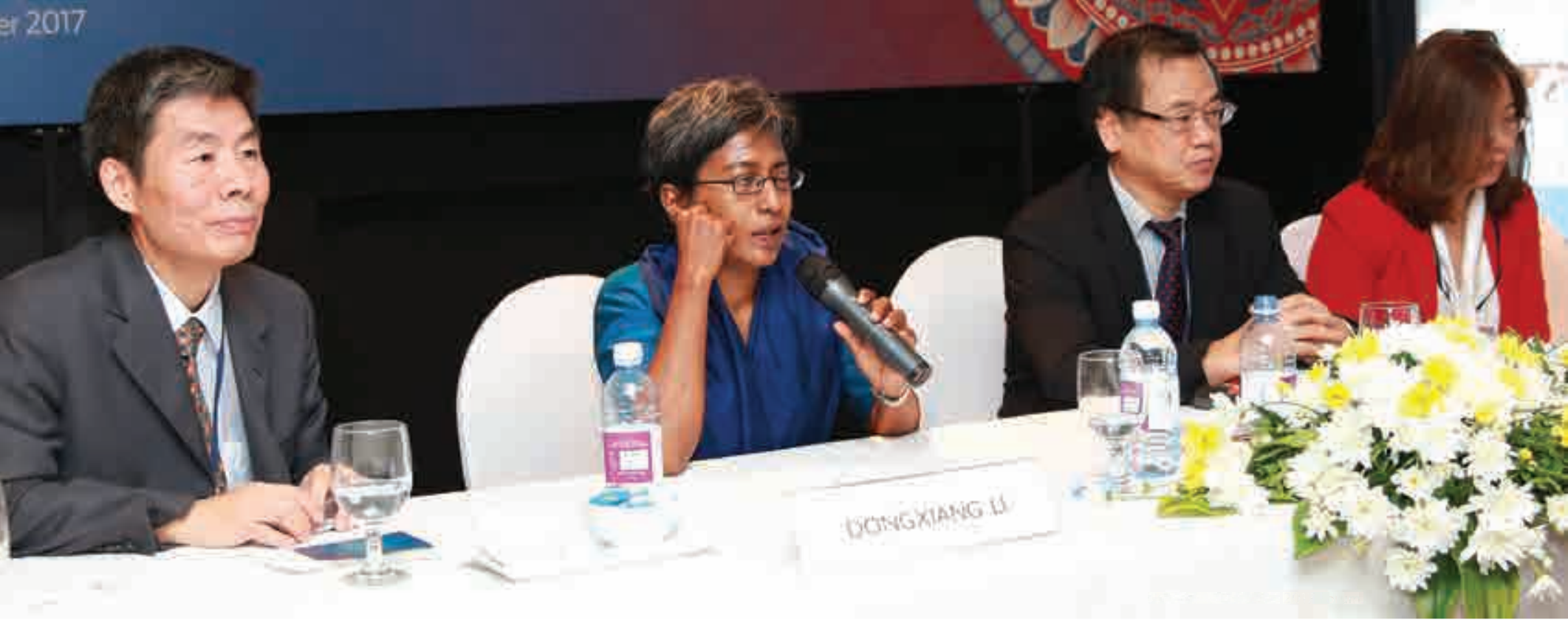

\section{SESSION 4: ADB-ASIAN THINK TANKS NETWORK: THE WAY FORWARD}

Juzhong Zhuang of ADB moderated the closing session.

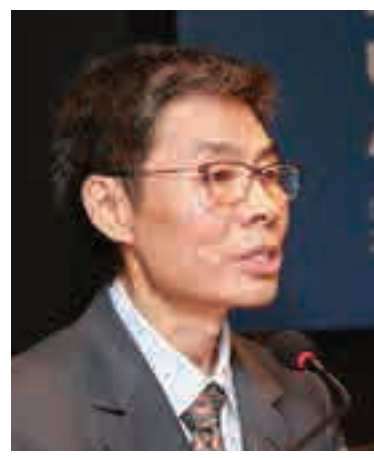

\section{Accomplishments and Next Steps}

Dongxiang Li of ADB presented a brief overview of the ADB-Asian Think Tanks Network (ATTN): its organization, past activities, and themes. He stressed the increasingly important role of Asian think tanks in policy formulation and implementation. ADB takes pride in providing the platform for enhancing systematic knowledge-sharing and strengthening the capacities of ATTN members by organizing the annual development forum since 2013 Li said. He expressed optimism that as a joint initiative of ADB and Asian Think Tank, the network will be sustained and operated largely by the participating think tanks.

Zhuang announced that Xiaoming Huang offered to host the next development forum in New Zealand, and that ADB and the network members greatly appreciated this kind gesture. Cyn-Young Park assured the participants that ADB will continue to deliberate on how to make the ATTN collaboration more useful and upgrade the annual forum to produce tangible outputs. She encouraged participants to provide comments and suggestions to this end.

\section{Participants' Feedback}

All of the respondents agreed that the forum achieved its objectives. They said the content was substantive and useful to their work, and they would likely pursue linkages with other think tanks after the forum. The overall quality of the forum was assessed as good or excellent and most of the participants agreed that ADB should continue to support the think tank network. 


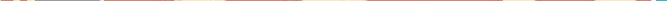

\section{APPENDIXES}




\section{Appendix 1: Program Agenda}

\section{September 2017 - Day 1}

Session 1: Opening Ceremony

Moderator: Dushni Weerakoon, acting executive director, Institute of Policy Studies (IPS)

\section{Time Speaker and Affiliation}

9:30 a.m.

Welcome Remarks

Dushni Weerakoon, acting executive director, IPS Sri Lanka

Sri Widowati, country director, ADB resident mission in Sri Lanka

9:45 a.m.-10:00 a.m. Keynote Address

Patali Champika Ranawaka, minister of Megapolis and Western

Development, Government of Sri Lanka

10:00 a.m.-10:30 a.m. Photo session and coffee break

\section{Session 2: Regional and Country Economic Outlook}

The session provided an overview of regional integration trends and issues in Asia. Country economic outlook presentations with subregional impact followed featuring the economies of the People's Republic of China, India, and Sri Lanka.

Moderator: Anbumozhi Venkatachalam, senior economist, Economic Research Institute for ASEAN and East Asia

\section{Time}

10:30 a.m. $-11: 05$ a.m

11:05 a.m.-11:50 a.m.

\section{Speaker and Affiliation}

Regional Integration in Asia: Trends and Issues

Cyn-Young Park, director, ADB

Open discussion

Country Presentations:

People's Republic of China's Economic Outlook

Qiangwu Zhou, director general, International Economics and Finance Institute

\section{India's Economic Outlook}

Radhicka Kapoor, research fellow, Indian Council for Research on International Economic Relations

\section{Sri Lanka's Economic Outlook}

Kithmina Hewage, research officer, IPS Sri Lanka

11:50 a.m. $-12: 20$ p.m.

Open discussion

12:20 p.m.-1:30 p.m. Lunch 


\section{Session 3: Financing for Sustainable Urbanization in Asia and the Pacific}

Participants discussed Asia's infrastructure needs and how they could be met. Country experiences in meeting urban infrastructure requirements for housing, solid waste, water supply and land were featured. Incentive schemes for public-private partnerships are discussed as well as the financing of the PRC's Belt and Road Initiative.

Moderator: Nonarit Bisonyabut, research fellow, Thailand Development Research Institute

\section{Time Speaker and Affiliation}

1:30 p.m.-2:15 p.m. Meeting Asia’s Infrastructure Needs

Juzhong Zhuang, deputy chief economist, ADB

Open discussion

2:15 p.m.-3:00 p.m. Country Presentations:

Financing for Urban Infrastructure in the Era of Climate Change and

Disaster Risks: Philippines

Marife Ballesteros, vice president, Philippine Institute for Development Studies

Potential Financial Instruments toward Sustainable Urban Infrastructural Development in Indonesia

Carunia Mulya Firdausy, senior research fellow, Economic Research Centre-Indonesian Institute of Sciences

Sustainable Financing for Urban Solid Waste Disposal Services in Sri Lanka

Bilesha Weeraratne, research fellow, Institute of Policy Studies of Sri Lanka

3:00 p.m.-3:30 p.m. Open discussion

3:30 p.m. $-4: 00$ p.m. $\quad$ Coffee break 
4:00 p.m.-5:00 p.m. Moderator: Shiro Patrick Armstrong, director, East Asian Bureau of Economic Research, Crawford School of Public Policy, The Australian National University

Country Presentations:

Dynamics of Financing and Governances of Melamchi Water Supply

Project in Kathmandu, Nepal: Lessons Learned

Ram Kumar Phuyal, associate professor, Center for Economic Development and Administration, Tribhuvan University

Financing the Belt and Road Initiative of the People's Republic of China Qiangwu Zhou, director general, International Economics and Finance Institute

Land Conversion during the Urbanization Process in Viet Nam: Current Status, Problems and Solutions

Tran Kim Chung, vice president, Central Institute for Economic Management

Public-Private Partnerships with a Governmental Fund: an Optimal Incentive Device

Keiichiro Oda, research fellow, Research Institute of Economy, Trade and Industry

5:00 p.m.-6:00 p.m. Open discussion

6:00 p.m.

Dinner (hosted by IPS Sri Lanka)

\section{September 2017 - Day 2}

Session 3: Financing for Sustainable Urbanization in Asia and the Pacific

Participants discussed in detail the fiscal implications of urbanization. Presentations featured on infrastructure investments and the promotion of small and medium-sized enterprises. The relationship between rural and urban areas was also examined.

Moderator: Derek Brien, executive director, Pacific Institute of Public Policy

\section{Time Speaker and Affiliation}

9:00 a.m.-9:40 a.m. Fiscal Implications of Urbanization

Sanjeev Gupta, deputy director, International Monetary Fund-Fiscal

Affairs Department

Open discussion

9:40 a.m.-9:50 a.m. Infrastructure Investment, Small and Medium-Sized Enterprises Promotion and Education for Sustainable Growth (video presentation)

Naoyuki Yoshino, dean, Asian Development Bank Institute (ADBI) 
Country Presentations:

The State of Urban Living: a Review of Housing Laws and Financing Instruments in Urban Pakistan

Shujaat Farooq, senior research economist, Pakistan Institute of Development Economics

Global Capital Supply and Sustainable Urbanization: Investment-Led Development Financing

Xiaoming Huang, professor and director, Wellington Network of AsiaPacific Research \& Policy, Victoria University of Wellington

Dynamic Relationship between Rural and Urban Areas

Enkhbaigali Byambasuren, president, Analysis Group of Mongolia

Financing for Effective, Inclusive and Sustainable Urbanization - People's Republic of China Case

Li Xu, senior research fellow, ADBI

10:50 a.m.-11:20 a.m. Open discussion

11:20 a.m.-11:40 a.m. Coffee break

\section{Session 4: ADB-Asian Think Tanks Network: The Way Forward}

Participants discussed future directions for the ADB-Asian Think Tanks Network.

\section{Time Speaker and Affiliation}

11:40 a.m.-11:50 a.m. ATTN accomplishments

Dongxiang Li, lead regional cooperation specialist, ADB

11:50 a.m.-12:00 p.m. Options/Next Steps for the ADB-Asian Think Tank Network

Juzhong Zhuang, deputy chief economist, ADB

12:00 p.m.-12:30 p.m. Open discussion

12:30 p.m.-12:35 p.m. Concluding remarks:

ADB and IPS Sri Lanka

12:35 p.m.-2:00 p.m. Lunch

\section{Networking Session}

\section{Time}

2:00 p.m.-5:30 p.m. Cultural site visit and networking activity (hosted by IPS Sri Lanka) 


\section{Appendix 2: List of Participants}

\section{Think Tanks}

\section{Afghanistan}

- Ahmad Masoud, senior communications officer, Afghanistan Research and Evaluation Unit

\section{Armenia}

- Melik Gasparyan, chief executive officer, AVAG Solutions Ltd

\section{Australia}

- Shiro Armstrong, Australian National University, East Asian Bureau of Economic Research, Crawford School of Public Policy

\section{Azerbaijan}

- Ayaz Chaparli, research fellow, Center for Analysis and Communication for Economic Reforms

\section{Bangladesh}

- Khan Ahmed Sayeed Murshid, director general, Bangladesh Institute of Development Studies

\section{Cambodia}

- Phalla Chem, deputy director, Cambodia Development Resource Institute

\section{China, People's Republic of}

- Qiu Aijun, deputy director general, China Center for Urban Development

- Yushu Feng, director, Regional Cooperation Institute

- Hu Wang, researcher, International Economics and Finance Institute

- Chen Xi, section chief, International Economics and Finance Institute

- Qiangwu Zhou, director general, International Economics and Finance Institute

\section{Georgia}

- Sophiko Skhirtladze, head of research center, ISET Policy Institute

\section{India}

- Radhicka Kapoor, research fellow, Indian Council for Research on International Economic Relations

\section{Indonesia}

- Carunia Mulya Hamid Firdausy, senior research fellow, National Center for Economics Research, Indonesian Institute of Sciences LIPI 


\section{Japan}

- Keiichiro Oda, senior research fellow, Research Institute of Economy, Trade and Industry

\section{Kazakhstan}

- Altynbek Akpanov, deputy director, Center of Industry Analysis, Economic Research Institute, Ministry of National Economy

\section{Korea, Republic of}

- Jeong-Ho Kim, professor, Korea Development Institute School of Public Policy and Management

\section{Kyrgyz Republic}

- Nuradil Baidoletov, deputy director, National Institute of Strategic Studies

\section{Malaysia}

- Zakariah bin Abdul Rashid, executive director, Malaysian Institute of Economic Research

\section{Mongolia}

- Enkhbaigali Byambasuren, president, Analysis Group

\section{Myanmar}

- Min Zar Ni Lin, deputy director of research program, Myanmar Development Research Institute, Centre for Economic and Social Development

\section{Nepal}

- Ram Chandra Dhakal, executive director, Center for Economic Development and Administration, Tribhuvan University

- Ram Phuyal, associate professor, Center for Economic Development and Administration, Tribhuvan University

\section{New Zealand}

- Xiaoming Huang, professor and director, Wellington Network of Asia-Pacific Research \& Policy, Victoria, University of Wellington

\section{Pakistan}

- Shujaat Farooq, senior research economist, Pakistan Institute of Development Economics

\section{Philippines}

- Marife Ballesteros, vice president, Philippine Institute for Development Studies

\section{Sri Lanka}

- Kithmina Hewage, research officer, Institute of Policy Studies

- Dushni Weerakoon, executive director, Institute of Policy Studies

- Bilesha Weeraratne, research fellow, Institute of Policy Studies 


\section{Thailand}

- Nonarit Bisonyabut, research fellow, Thailand Development Research Institute

\section{Uzbekistan}

- Sharofiddin Nazarov, director, Centre for Economic Research

\section{Vanuatu}

- Derek Brien, executive director, Pacific Institute of Public Policy

\section{Viet Nam}

- Tran Kim Chung, vice president, Central Institute for Economic Management

\section{Regional Think Tanks}

- Li Xu, senior research fellow, Asian Development Bank Institute

- Ziqian Liang, deputy director, Central Asia Regional Economic Cooperation (CAREC) Institute

- Khalid Umar, senior strategic planning officer, CAREC Institute

- Anbumozhi Venkatachalam, senior economist, Economic Research Institute for ASEAN and East Asia

\section{Other Participants from Sri Lanka}

- Charmini De Silva, assistant news editor, DailyFT

- Ajith Dissanayake, head of the department of economics, University of Kelaniya

- Priyanga Dunusinghe, senior lecturer, University of Colombo

- Nalin Fernandopulle, journalist, Sunday Observer

- Sarasali Fonseka, UNDP

- R. Gunasekara, Economynext

- Sriyani Hulugalle, formerly from World Bank

- Malathy Knight, research director, Verite Research Pvt Ltd

- Nirmani Liyanage, Centre for Poverty Analysis (CEPA)

- M. F. A. Mubarak, director, National Planning Department

- Roshan Perera, senior economist, Central Bank of Sri Lanka

- Rohan Samarajiva, chair, LIRNEasia

- Sithara Senani, journalist, Daily News

- Yohan, Sirara TV

- Chantal Sirisena, Ministry of Finance

- T. Sivakumar, senior lecturer, University of Moratuwa

- Ajitha Tennakoon, Department of Economics, University of Kelaniya

- Indu Weerasoori, project manager/urban, UN Habitat

- Ashra Wickramathilalka, Centre for Poverty Analysis (CEPA) 


\section{Asian Development Bank}

- Sharon Lynn Dela Torre, consultant

- Tadateru Hayashi, senior country economist, SLRM

- Savindi Jayakody, SLRM

- Dongxiang Li, lead regional cooperation specialist, SARD

- Cyn-Young Park, director, ERCD

- Aiko Kikkawa Takenaka, economist, ERCD

- Hasitha Wickremasinghe, senior economics officer, SLRM

- Sri Widowati, country director, Sri Lanka Resident Mission (SLRM)

- Juzhong Zhuang, deputy chief economist and deputy director general, Economic Research and Regional Cooperation Department (ERCD)

\section{Institute of Policy Studies of Sri Lanka}

- Nisha Arunatilake, research fellow

- Samanthi Bandara, research officer

- Gavin Dissanayake, project officer

- Nayomi Jayakody, secretary

- Shihara Maduwage, manager, Communications \& Strategic Outreach

- Semini Satarasinghe, project intern

- Chinthani Sooriyamudali, research officer

- Ganga Tilakaratna, research fellow

- Kanchana Wickramasinghe, research economist

- Charmaine Wijesinghe, manager, Publications and Events 


\section{Appendix 3: Forum Partner}

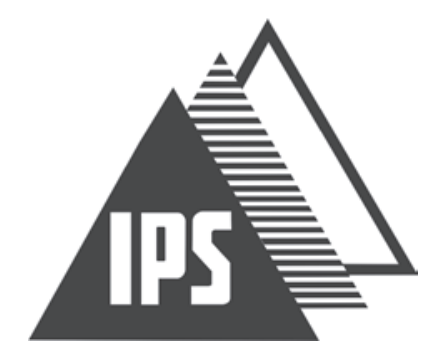

\section{Institute of Policy Studies of Sri Lanka}

The Institute of Policy Studies of Sri Lanka (IPS) is an autonomous economic research organization, established by an Act of Parliament. Its mission is to conduct high-quality, independent, policy-relevant research to provide robust evidence for policymaking and improve the lives of all Sri Lankans.

Since its formal establishment in 1990, the IPS has come to be recognized as a center of excellence in economic policy research. An important feature of its research is its coverage of many of the major areas of relevance to current socioeconomic policy issues in Sri Lanka and the Asian region. The complementary expertise of its researchers is the key source of strong empirically-based evidence to support economic policymaking, disseminated widely through reports, research papers, journal articles, and public presentations.

The IPS was conceived in the mid-1980s as an autonomous institution designed to promote policy-oriented economic research and to strengthen the capacity for medium-term policy analysis in Sri Lanka. It was established by an Act of Parliament in December 1988 and was formally set up as a legal entity by gazette notification in April 1990. From its inception, the IPS was supported through a collaborative project between the Royal Netherlands Government and the Government of Sri Lanka under four phases of operations to allow the Institute to gradually diversify its income and resource base. In the interim, the IPS has been successful in establishing its own Endowment Fund and setting in motion the transition to full financial independence with the formal ending of the fourth phase of operations in June 2006. The IPS moved to its own head office in September 2010.

The IPS functions under the key ministries involved in economic policy making and implementation in Sri Lanka, working closely with the government, private sector, development partners, civil society, and academia. 
Appendix 4: Gallery

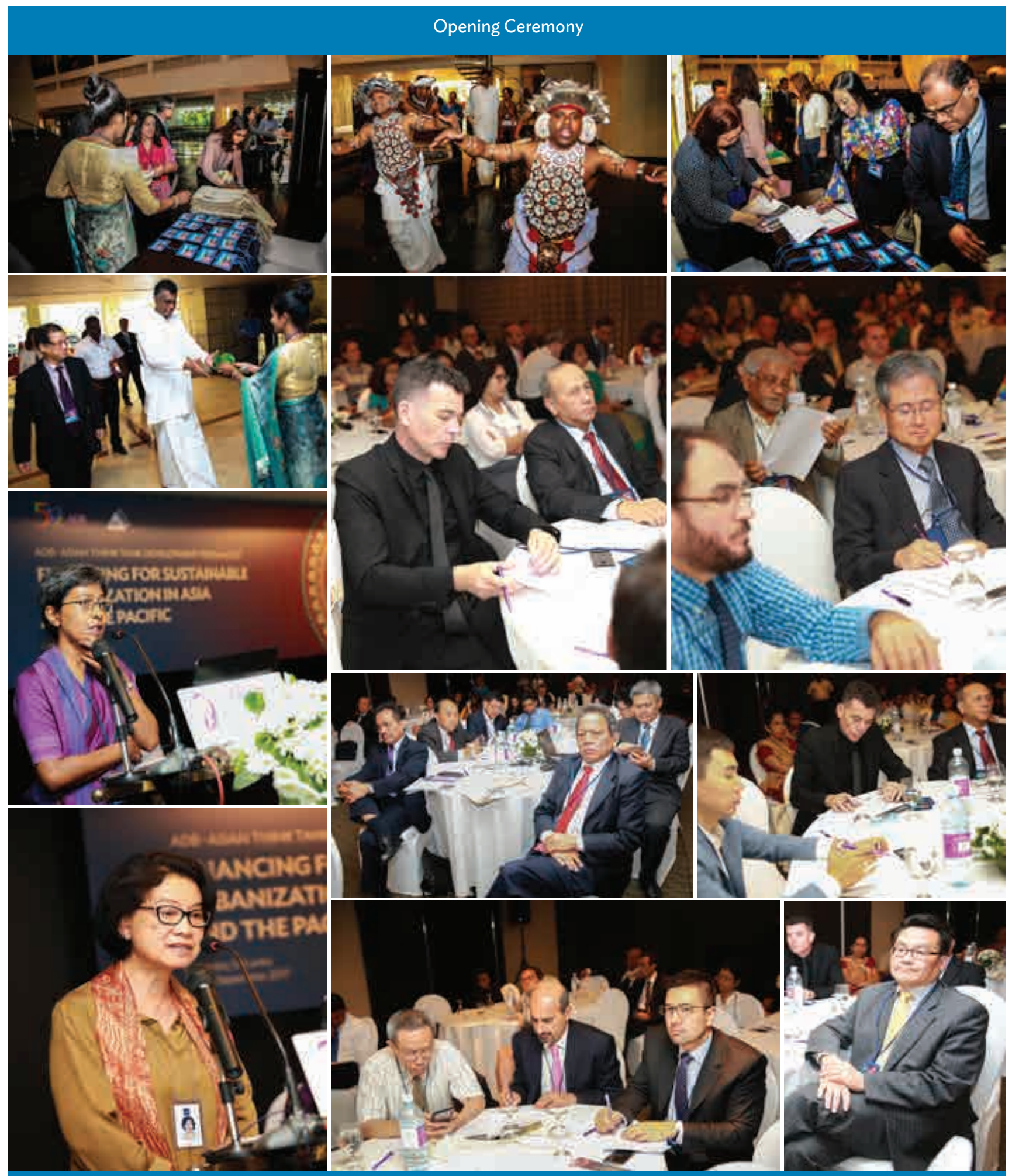

Participants of the forum were treated to a special opening ceremony prior to the welcome speeches. 


\section{Day 1 Sessions}
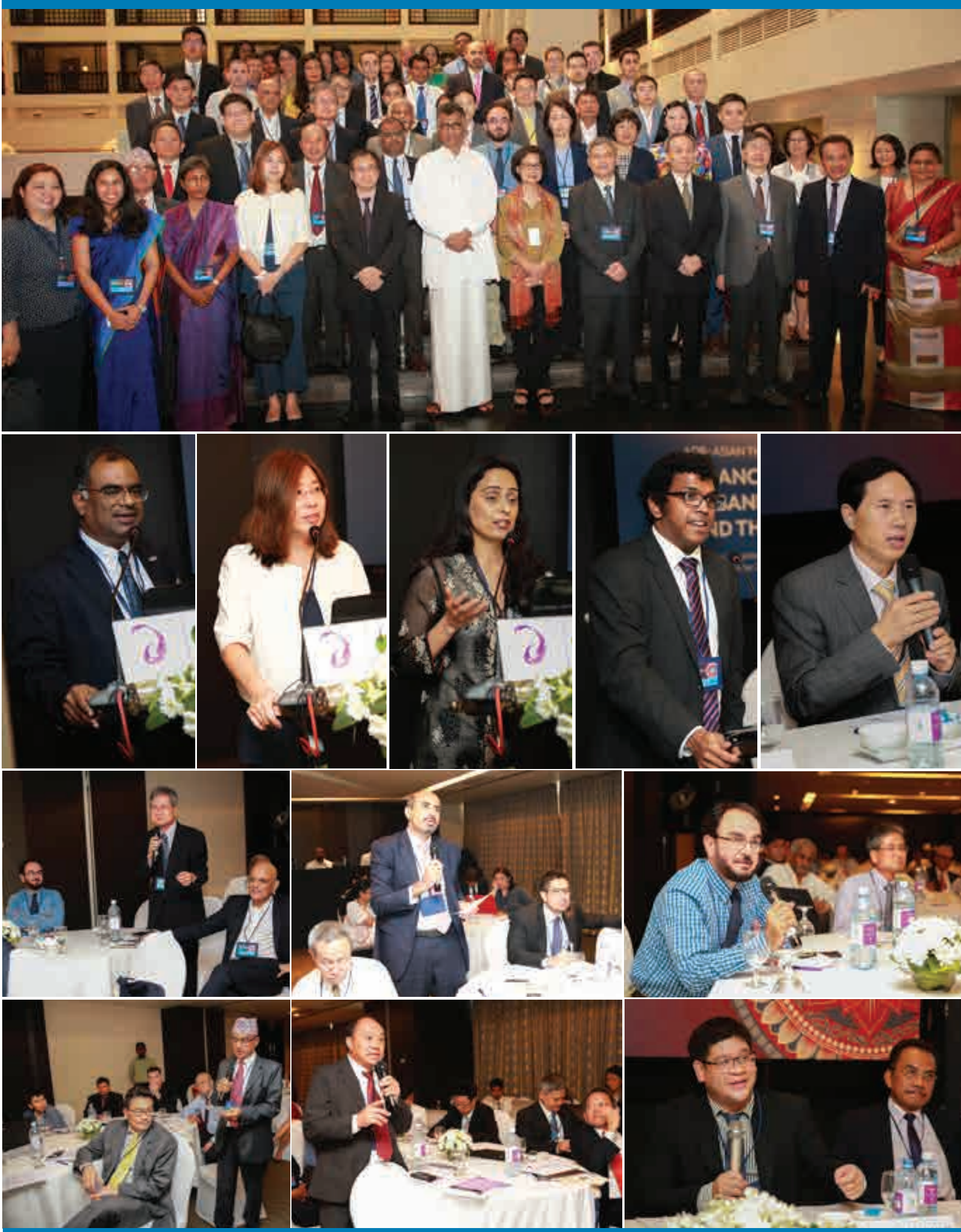

After the formal photo of all forum participants, discussions on economic outlooks and country presentations followed. 

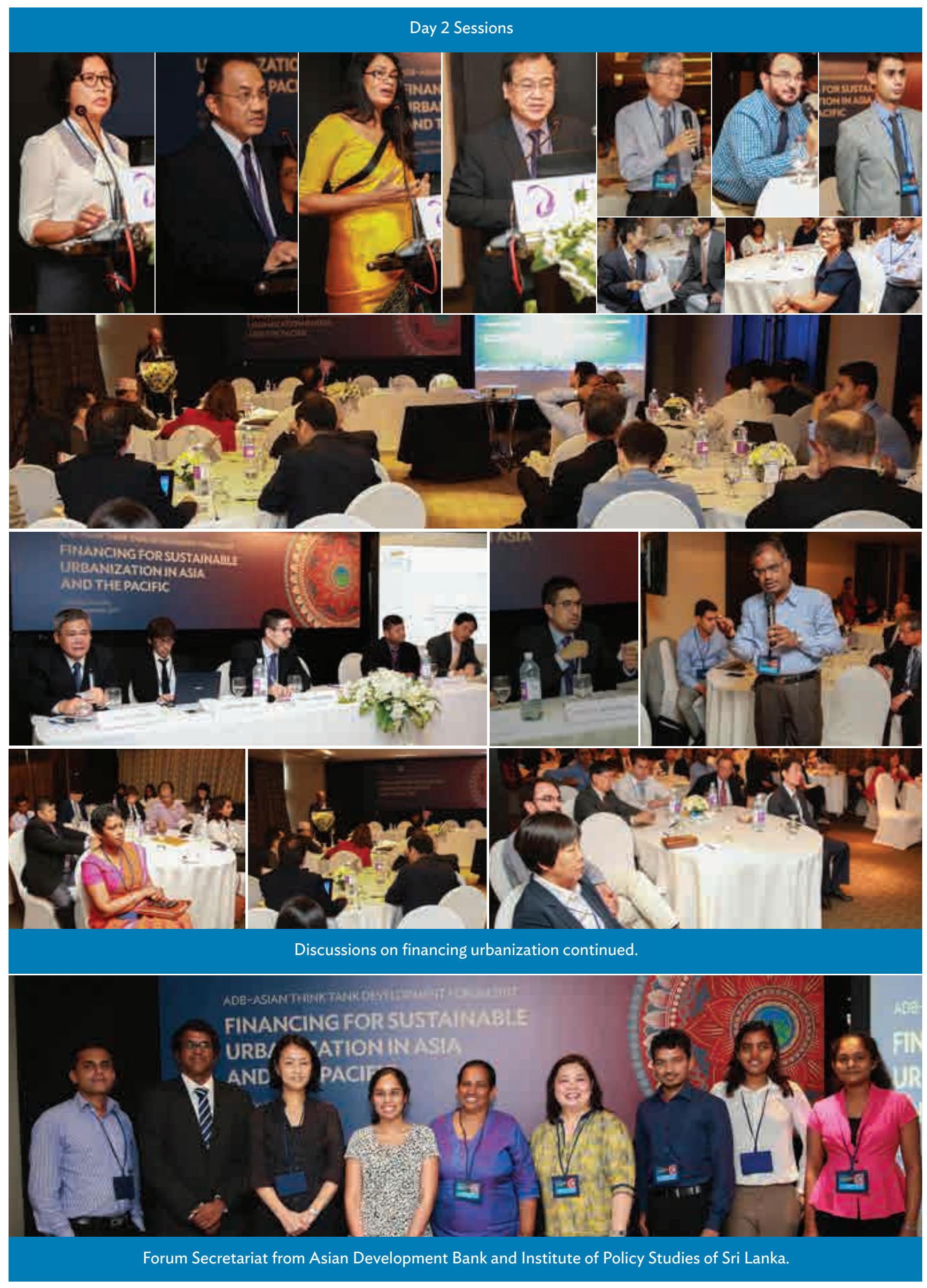





\section{Financing for Sustainable Urbanization in Asia and the Pacific}

Proceedings of the ADB-Asian Think Tank Development Forum 2017

The ADB-Asian Think Tanks Network held its annual knowledge-sharing event on 20-21 September 2017 in Colombo, Sri Lanka. This publication captures the proceedings of the forum, which featured presentations on the regional economic outlook and various financing schemes for urban infrastructure projects. The network, comprising 43 prominent think tanks in Asia, aims to promote knowledge sharing and capacity building toward better policy support for governments.

\section{About the Asian Development Bank}

ADB is committed to achieving a prosperous, inclusive, resilient, and sustainable Asia and the Pacific, while sustaining its efforts to eradicate extreme poverty. Established in 1966, it is owned by 67 members -48 from the region. Its main instruments for helping its developing member countries are policy dialogue, loans, equity investments, guarantees, grants, and technical assistance.

\section{ADB}

ASIAN DEVELOPMENT BANK

6 ADB Avenue, Mandaluyong City 1550 Metro Manila, Philippines www.adb.org 